\title{
Ecological state of the floodplain-channel complexes of small rivers in Novosibirsk
}

\author{
Natalya Sineeva ${ }^{1, *}$, Inna Makarikhina ${ }^{1}$, and Alexander Vysokih $^{1}$ \\ ${ }^{1}$ Novosibirsk State University of Architecture and Civil Engineering (SIBSTRIN), Turgeneva str., \\ 159, 630008, Novosibirsk, Russia
}

\begin{abstract}
The relevance of this study is due to the increasing man-made stress on water bodies and the land resources connected with them within the urbanized territories, as a result, changes in the morphology and dynamics of river channels and floodplain. It leads to the need for an integrated environmental assessment of floodplain-riverbed complexes, especially small rivers within urbanized areas. The purpose of the study is an integrated environmental assessment of floodplain-channel complexes of small rivers in the city of Novosibirsk to substantiate the recommendations of engineering measures to reduce environmental tensions. The research results showed that the Yeltsovka and the Plyushchikha rivers belong to the group with weak environmental intensity, the Tula, the Yeltsovka-2, the Kamenka, the Kamyshenka are of medium environmental intensity, the Yeltsovka-1 is with strong environmental tension. Significance of the study is that the integral assessment of the floodplain-channel complex of small rivers in the city of Novosibirsk can be used to substantiate the recommendations of engineering measures to reduce environmental tensions, which should be selected based on the obtained integral points, as well as to prevent accidents at various facilities or communications during engineering construction or water engineering design, construction and operation.
\end{abstract}

\section{Introduction}

Large-scale and diversified use of water and land resources connected with them is accompanied by a noticeable deterioration of the ecological situation on the rivers and river valleys, associated with such changes in the morphology and dynamics of the river channels, nature of floodplains, which adversely affect life and conditions of people economic activity, on the one hand, and with the strengthening of dangerous manifestations of channel processes on the other. At the same time, insufficient consideration of natural river layer deformations or forecast errors in engineering and water engineering design led to the emergence situation at many facilities and communications, their partial or complete destruction, and the need to protect the river layer from deformations.

As a result, there is a need to give a general assessment of the ecological state of the entire floodplain-channel complex, since the river channels and floodplains are

*Corresponding author: michmacha@mail.ru 
interconnected both genetically (the flood plain is a derivative of the development of the river layer) and in their mutual influence on each other. Therefore, the natural change of the channels and their anthropogenic transformation determine not only the river component of environmental stress, but also influence the landscape maps in spite of their great width and relative remoteness of floodplain landscapes from the river itself [6].

Anthropogenic factors analysis made it possible to identify those that had the most noticeable effect on adverse changes in channel processes, channel morphology and floodplain, and the ecological state of the rivers as a whole [7].

The processes and phenomena that determine the ecological status of small rivers of agglomerations include anthropogenic silting and degradation of the channels (as a result of soil erosion in the catchment areas and in the rivers' floodplains, city industrial pollution and low ecological culture of the population); changes in floodplain landscapes associated with agricultural and industrial production, development of the territory. The use of the river channels as waste water receivers (collector), agricultural development of floodplains, as well as their intersection utilities, etc are of great importance.

These phenomena differ significantly in their structure, method of measurement and nature of distribution. This makes it difficult to work out a single criterion of the rivers' ecological state, which would integrate private assessments associated with each of the phenomena that determine it. At the same time, an objective complex assessment of the ecological state of the river's floodplain-channel complex, its comparison with other rivers and the spatial analysis of the phenomena as a whole are impossible without such a criterion.

The purpose of this work is an integrated environmental assessment of floodplainchannel complexes of small rivers in Novosibirsk to substantiate the recommendations of engineering measures to reduce environmental tensions.

At present, the small rivers in the city of Novosibirsk are used to collect surface drains without their respective treatment, removal of wastewater from enterprises and the population, as well as recreation. There are unauthorized dumping of household waste, large-litter garbage near water bodies. The main sources of pollution are also the products of coastal erosion, damage to coastal vegetation due to urban planning. As a result, small rivers are polluted $[3,5]$.

The integrated environmental assessment of floodplain-channel complexes of small rivers in Novosibirsk was carried out in three stages:

1 - selection of the main phenomena and processes that have the most noticeable impact on the ecological condition of the channels and rivers' floodplains and causing their adverse changes;

2 - justification of the criteria for assessing environmental stress for each of the factors and their ranking;

3 - obtaining a generalized indicator of the ecological state of the floodplain-channel complex, which takes into account the influence of each particular phenomenon and process on the overall ecological situation in river valleys.

\section{Materials and methods}

The assessment of environmental stress associated with each type of process or anthropogenic changes in the floodplain-channel complex is ranked by five gradations, each of which is assigned a score depending on the degree of influence: no negative impact corresponds to 0 points; the phenomena that caused the most adverse effects cost 5 points. The introduction of the scoring makes it possible to obtain an integral assessment of the rivers' ecological tension, taking into account all the factors that determine it [8].

The forms of channel processes manifestation listed below in Tables $1-5$ are due to 
various channel-forming factors, and the criteria for their assessment as indicators of environmental stress differ significantly in their structure, method of measurement, and nature of distribution.

Table 1. Criteria for environmental stress caused by natural deformations of the river channels.

\begin{tabular}{|c|c|c|}
\hline \multirow{2}{*}{$\begin{array}{c}\text { Environmental } \\
\text { tensions } \\
\text { points }\end{array}$} & \multicolumn{2}{|c|}{ Shores erosion } \\
\cline { 2 - 3 } & Average speed $\mathrm{m} /$ year & $\begin{array}{c}\text { The length of erosion zones, \% out } \\
\text { of the river length }\end{array}$ \\
\hline 0 & 0 & 0 \\
\hline 1 & $0-0.1$ & $0-5$ \\
\hline 2 & $0.1-0.5$ & $5-20$ \\
\hline 3 & $0.5-2$ & $20-60$ \\
\hline 4 & $>2$ & $>60$ \\
\hline 5 & \multicolumn{2}{|c|}{ are absent on the rivers of Russia } \\
\hline
\end{tabular}

Table 2. Criteria for the environmental stress on rivers associated with adverse manifestations of natural and anthropogenic changes in the hydrological regime of rivers.

\begin{tabular}{|c|c|c|}
\hline $\begin{array}{c}\text { Environmental } \\
\text { tensions points }\end{array}$ & Seasonal drying days / year & Reduced river flow, \% \\
\hline 0 & absent & 0 \\
\hline 1 & $0-10$ & $0-10$ \\
\hline 2 & $10-30$ & $10-25$ \\
\hline 3 & $30-60$ & $25-50$ \\
\hline 4 & $60-90$ & $>50$ \\
\hline 5 & $>90$ & - \\
\hline
\end{tabular}

Table 3. Criteria for environmental stress associated with accumulative processes in the river layers, their siltation and degradation.

\begin{tabular}{|c|c|c|}
\hline $\begin{array}{c}\text { Environmental } \\
\text { stress points }\end{array}$ & Length of silting zones, $\%$ & Characteristic \\
\hline 0 & 0 & - \\
\hline 1 & $0-5$ & Weak natural silting \\
\hline 2 & $5-30$ & Alternation of silted and non-silted areas \\
\hline 3 & $30-70$ & Average degree of siltation \\
\hline 4 & $70-90$ & $\begin{array}{c}\text { Strong siltation and degradation of the } \\
\text { rivers of 1-3 magnitude orders }\end{array}$ \\
\hline 5 & $90-100$ & $\begin{array}{c}\text { Strong siltation and degradation of the } \\
\text { rivers, the rivers shallowing }\end{array}$ \\
\hline
\end{tabular}

Table 4. Criteria for environmental stress on rivers associated with mechanical changes in channels, the influence of hydroelectric complexes and other water management measures.

\begin{tabular}{|c|c|c|}
\hline \multirow{2}{*}{$\begin{array}{c}\text { Environmental } \\
\text { tensions points }\end{array}$} & \multicolumn{2}{|c|}{ Mechanical variation of the river layers } \\
\cline { 2 - 3 } & On the free sites, $\%$ & In urban areas \\
\hline 0 & 0 & Missing \\
\hline 1 & $0-10$ & Very weak \\
\hline 2 & $10-25$ & Weak \\
\hline 3 & $25-50$ & Average \\
\hline 4 & $50-90$ & Strong \\
\hline 5 & $90-100$ & Complete \\
\hline
\end{tabular}


Table 5. Criteria of environmental stress associated with anthropogenic changes in river floodplains.

\begin{tabular}{|c|c|c|}
\hline \multirow{2}{*}{$\begin{array}{l}\text { Environmental } \\
\text { tensions } \\
\text { points }\end{array}$} & \multicolumn{2}{|c|}{ Mechanical variation of the river layers } \\
\hline & $\begin{array}{c}\text { In connection with agricultural } \\
\text { use }\end{array}$ & In urban areas \\
\hline 0 & Unchanged & Unchanged \\
\hline 1 & $\begin{array}{l}\text { Weak (depletion of the species } \\
\text { vegetation composition, local soil } \\
\text { degradation and relief change) }\end{array}$ & $\begin{array}{l}\text { Weak (separate communications and } \\
\text { sites) }\end{array}$ \\
\hline 2 & $\begin{array}{l}\text { Medium (partial uprooting of } \\
\text { forests, partial plowing) }\end{array}$ & $\begin{array}{l}\text { Medium (partial building, laying } \\
\text { communications) }\end{array}$ \\
\hline 3 & $\begin{array}{l}\text { Strong (full plowing with relief } \\
\text { planning, partial embankment) }\end{array}$ & $\begin{array}{l}\text { Strong (partial reclamation and diking, } \\
\text { separate sandpits, communications) }\end{array}$ \\
\hline 4 & $\begin{array}{l}\text { Very strong (the same, but with } \\
\text { full collapse, draining of the } \\
\text { floodplain) }\end{array}$ & $\begin{array}{l}\text { Very strong (the same one, but with a } \\
\text { complete dipping, treatment plant } \\
\text { location) }\end{array}$ \\
\hline 5 & - & $\begin{array}{l}\text { Full (alluvium and building, solid pits, } \\
\text { mass communications, landfills, etc.) }\end{array}$ \\
\hline
\end{tabular}

The calculation of the points sum was made taking into account the weight correction factors (table 6). Siltation and degradation of the small rivers is a phenomenon that has an extremely negative effect on the ecological condition not only of the river, but also the adjacent territories, has 1 coefficient, therefore, the corresponding score (from 1 to 5) without changes is included in the points' sum. On the contrary, coastal erosion significantly less affect the ecological situation; their role is estimated with a weighting factor of 0.6: if the erosion of the rivers' banks occurs at a speed of more than $10 \mathrm{~m} /$ year, which corresponds to 5 points, it will be counted in the sum of points $5 \times 0.6=3$.

Table 6. Weights coefficients, taking into account the role of changes factors in the channels and the floodplain in the overall assessment of environmental stress on small rivers.

\begin{tabular}{|c|c|}
\hline Factors of the ecological state of the small river & $\begin{array}{c}\text { Weight } \\
\text { coefficient }\end{array}$ \\
\hline Siltation & 1.0 \\
\hline Scour shores & 0.6 \\
\hline Seasonal drying & 0.8 \\
\hline Reduced water flow due to water intake for industrial needs and irrigation & 1.0 \\
\hline Changes in floodplain landscapes in agricultural use floodplains & 0.6 \\
\hline Mechanical changes in industrial areas & 1.0 \\
\hline
\end{tabular}

Floodplains plowing for agricultural purposes are taken into account with the same coefficient. At the same time, the mechanical change in the floodplains associated with construction, or their pollution in industrial sites, is estimated with 1 factor. The maximum possible amount of points is obtained by adding the maximum points for each indicator. We can assume that all small rivers are completely silted in some territory, which corresponds to $5 \times 1=5$ points, their banks are washed out with a maximum speed of $5 \times 0.6=3$ points, they dry up more than 90 days a year $5 \times 0.8=4$ points, their maximum water intake is $5 \times 1=5$ points, the floodplains are completely changed during agricultural $(5 \times 0.6=3$ points $)$ and industrial $(5 \times 1=5$ points $)$ use.

Then this territory will be characterized by the maximum possible amount of points 25 , which should mean environmental tensions (in real conditions, this combination of phenomena is not observed, but theoretically possible), corresponding to the environmental crisis situation. The resulting amount of private points can be divided into 5 grades, each of 
which is assigned a score, taken as an integral indicator of the ecological situation associated with anthropogenic influence on the river layers and floodplains, adverse manifestations of the river and rivers' hydrological regimes.

The first grade includes the sum of private points from 0 to 5 ; it is assigned one integral environmental stress score on rivers, 1 . The second gradation with the sums from 5 to 10 points is assigned a score of 2, the third gradation is 10-15 - a score of 3, the fourth is $15-20$ - a score of 4 and the fifth is $20-25$ - a score five.

\section{Results}

The results below are of an integrated assessment of the small rivers' floodplain-channel complex in Novosibirsk. In total, 7 small rivers (the length of the river is up to $50 \mathrm{~km}$ ) flow through the territory of the city: Tula, Yeltsovka, Yeltsovka-1, Yeltsovka-2, Kamenka, Kamyshovka, Plyushchikha $[1,2,4]$.

According to the assessment results, the Tula River is assigned the third integral point, $45 \%$ of the length it is long, the banks are blurred at a rate of $15 \mathrm{~cm} /$ year, it dries out for 11-12 days during the year, the water content decreases by $25 \%$, on the floodplains the average building density. There is also a slight mechanical change in the floodplain. The combination of these factors creates an average environmental stress (Table 7).

Table 7. Integral assessment of the floodplain - channel complex of the Tula River 2.

\begin{tabular}{|l|c|c|c|}
\hline Factors & point & Weight coefficient & Total score \\
\hline Siltation & 3 & 1.0 & 3 \\
\hline Scour shores & 2 & 0.6 & 1.2 \\
\hline Seasonal drying & 2 & 0.8 & 1.6 \\
\hline Decrease in water flow & 3 & 1.0 & 3 \\
\hline Changing floodplain landscapes & 2 & 0.6 & 1.2 \\
\hline Mechanical change of the floodplain & 1 & 1.0 & 1 \\
\hline \multicolumn{2}{|c|}{ Total } & 11 \\
\hline
\end{tabular}

According to the results of the assessment, the Yeltsovka-2 River is assigned the third integral point, $80 \%$ of the length it is silted, the banks erodes at a rate of $20 \mathrm{~cm} /$ year, overflows for 4-5 days during the year, the water flow decreases by $25 \%$, on the floodplains the average building density, mechanical change of the floodplain is absent. The combination of these factors creates an average environmental stress (table 8).

Table 8. Integral assessment of the floodplain - channel complex of the 2 Yeltsovka River.

\begin{tabular}{|l|c|c|c|}
\hline \multicolumn{1}{|c|}{ Factors } & point & Weight coefficient & Total score \\
\hline Siltation & 4 & 1.0 & 4 \\
\hline Scour shores & 2 & 0.6 & 1.2 \\
\hline Seasonal drying & 1 & 0.8 & 0.8 \\
\hline Decrease in water flow & 3 & 1.0 & 3 \\
\hline Changing floodplain landscapes & 2 & 0.6 & 1.2 \\
\hline Mechanical change of the floodplain & 0 & 1.0 & 0 \\
\hline \multicolumn{2}{|c|}{ Total } \\
\hline
\end{tabular}

According to the results of the assessment, the Yeltsovka-1 River is assigned the fourth integral point, $95 \%$ of the length it is silted, the banks are washed out at a speed of $30 \mathrm{~cm} /$ year, it dries out for 30-40 days during the year, the water flow decreases by $30 \%$, and it is a strong building density on the floodplains. There is also a complete mechanical change in the floodplain. The combination of these factors creates strong environmental tensions (Table 9). 
Table 9. Integral assessment of the floodplain - channel complex of the Yeltsovka-1 River.

\begin{tabular}{|l|c|c|c|}
\hline Factors & point & Weight coefficient & Total score \\
\hline Siltation & 5 & 1.0 & 5 \\
\hline Scour shores & 2 & 0.6 & 1.2 \\
\hline Seasonal drying & 3 & 0.8 & 2.4 \\
\hline Decrease in water flow & 3 & 1.0 & 3 \\
\hline Changing floodplain landscapes & 3 & 0.6 & 1.8 \\
\hline Mechanical change of the floodplain & 5 & 1.0 & 5 \\
\hline Total & & 18.4 \\
\hline
\end{tabular}

According to the results of the assessment, the Kamenka River is assigned the third integral point, $90 \%$ of the length it is silted, the banks becomes blurred at a rate of $10-15$ $\mathrm{cm} /$ year, and it does not over dry during the year and does not reduce the water flow. On floodplains there is a very strong building density, there is also a complete mechanical change in the floodplain. The combination of these factors creates average environmental tensions (table 10).

Table 10. Integral assessment of the floodplain - channel complex of the Kamenka river.

\begin{tabular}{|l|c|c|c|}
\hline Factors & point & Weight coefficient & Total score \\
\hline Siltation & 5 & 1.0 & 5 \\
\hline Scour shores & 2 & 0.6 & 1.2 \\
\hline Seasonal drying & 0 & 0.8 & 0 \\
\hline Decrease in water flow & 0 & 1.0 & 0 \\
\hline Changing floodplain landscapes & 4 & 0.6 & 2.4 \\
\hline Mechanical change of the floodplain & 5 & 1.0 & 5 \\
\hline Total & & 13.6 \\
\hline
\end{tabular}

According to the results of the assessment, the Kamyshenka River is assigned the third integral point, because $99 \%$ of the length it is silted, the banks are blurred at a rate of $20 \mathrm{~cm}$ / year, it does not dry up and it does not decrease water flow during the year, there is a very high building density on the floodplains, full mechanical change of the floodplain. The combination of these factors creates average environmental tensions (table 11).

Table 11. Integral assessment of the floodplain - channel complex of the Kamyshenka River.

\begin{tabular}{|l|c|c|c|}
\hline Factors & point & Weight coefficient & Total score \\
\hline Siltation & 5 & 1.0 & 5 \\
\hline Scour shores & 2 & 0.6 & 1.2 \\
\hline Seasonal drying & 0 & 0.8 & 0 \\
\hline Decrease in water flow & 0 & 1.0 & 0 \\
\hline Changing floodplain landscapes & 4 & 0.6 & 2.4 \\
\hline Mechanical change of the floodplain & 5 & 1.0 & 5 \\
\hline Total & & 13.6 \\
\hline
\end{tabular}

According to the results of the assessment, the Plyushchikha River is assigned the second integral point, $15 \%$ of the length it is silted, the banks become blurred at a rate of 15 $\mathrm{cm} /$ year, it dries out for 2-3 days during the year, the water flow decreases by $10 \%$, on the floodplains the low building density, there is no change in floodplain. The combination of these factors creates weak environmental tensions (Table 12). According to the results of the assessment, the Yeltsovka River is assigned the second integral score, 35\% of the length it is silted, the banks are blurred at a speed of $50 \mathrm{~cm} /$ year, it dries out for 1-2 days during the year, the water content decreases by $10 \%$, on the floodplains the average building density, there is no mechanical change in floodplain. 
Table 12. The integral assessment of the floodplain - channel complex of the river Plyushchikha.

\begin{tabular}{|l|c|c|c|}
\hline Factors & point & Weight coefficient & Total score \\
\hline Siltation & 2 & 1.0 & 2 \\
\hline Scour shores & 2 & 0.6 & 1.2 \\
\hline Seasonal drying & 1 & 0.8 & 0.8 \\
\hline Decrease in water flow & 2 & 1.0 & 2 \\
\hline Changing floodplain landscapes & 2 & 0.6 & 1.2 \\
\hline Mechanical change of the floodplain & 0 & 1.0 & 0 \\
\hline Total & & 7.2 \\
\hline
\end{tabular}

The combination of these factors creates weak environmental tensions (Table 13).

Table 13. Integral assessment of the floodplain - channel complex of the Yeltsovka river.

\begin{tabular}{|l|c|c|c|}
\hline Factors & point & Weight coefficient & Total score \\
\hline Siltation & 3 & 1.0 & 3 \\
\hline Scour shores & 3 & 0.6 & 1.8 \\
\hline Seasonal drying & 1 & 0.8 & 0.8 \\
\hline Decrease in water flow & 1 & 1.0 & 1 \\
\hline Changing floodplain landscapes & 3 & 0.6 & 1.8 \\
\hline Mechanical change of the floodplain & 0 & 1.0 & 0 \\
\hline Total & & 8.4 \\
\hline
\end{tabular}

The Yeltsovka and Plyushchikha rivers belong to the group with weak environmental intensity, the Tula, the Yeltsovka-2, the Kamenka, the Kamyshenka are medium environmental intensity, the Yeltsovka-1 is with strong environmental intensity of floodplain-channel complexes.

Engineering measures are necessary in order to reduce environmental tensions, which should be selected on the basis of the obtained integral points: 0 points (no environmental tension) - no measures are required; 1 point (the initial stage of environmental tension) strengthening of the coast (shoreline) is recommended; 2 points (weak environmental tensions) - strengthening the coast; mechanical clearing of the channel; 3 points (average environmental stress) - strengthening the coast, mechanical and hydraulic-clearing the layers; 4 points (strong environmental tensions) - all the above-mentioned measures, as well as the restoration of water balance - a set of activities aimed at increasing the collection of surface runoff, as well as monitoring water intake from the river; 5 points (environmental crisis situation) - all of the above measures, as well as justification. It is possible to liquidate the object if further use of the water body is dangerous and recovery is not advisable.

\section{Conclusion}

The integral assessment of the floodplain-channel complex of small rivers in Novosibirsk can be used to substantiate the recommendations of engineering measures to reduce environmental tensions, prevent emergencies at various facilities or communications during engineering and construction or water management design, construction and operation.

\section{References}

1. N.V. Sineeva, E3S Web of Conferences, 33, 02050 (2018) https://doi.org/10.1051/e3sconf/20183302050

2. S.N. Balandin, Novosibirsk: history of town planning 1893 - 1945 (Zap.-Sib. Prince, Novosi-Birsk, 1978) 
3. N.V. Sineeva, Civil Engineering (Sibstrin) 11(1), 54-59 (2008)

4. N. Sineeva, Channel processes and their typification, textbook (Reg.Svyd-in, 2011)

5. A.L. Suzdaleva, Technogenesis and degradation of surface water bodies (Publishing House "ENERGY", Moscow, 2014)

6. R.S. Chalov, Environmental Ruslovodedenie (Moscow, 2000) 